\title{
Henoch-Schönlein Purpurasının Ciddiyetini Öngörmek: Fonksiyonel Trombosit Belirteçlerinin Rolü
}

\section{Predicting the Severity of Henoch-Schönlein Purpura: The Role of the Functional Platelet Indices}

\author{
${ }^{1}$ Nevzat Aykut BAYRAK, ${ }^{2}$ Cagatay NUHOGLU \\ ${ }^{1}$ Zeynep Kâmil Kadın ve Çocuk Hastalıkları Eğitim ve Araştırma Hastanesi, Çocuk Gastroenteroloji Kliniği, İstanbul, Türkiye \\ ${ }^{2}$ Haydarpaşa Numune Eğitim ve Araştırma Hastanesi, Çocuk Sağlığı Kliniği, İstanbul, Türkiye
}

Nevzat Aykut Bayrak: https://orcid.org/0000-0002-5553-6123

Cagatay Nuhoglu: https://orcid.org/0000-0003-2187-4121

\section{ÖZ}

Amaç: Amacımız tanı anında saptanan kalitatif trombosit belirteçlerinin Henoch-Schönlein purpurası'ndaki (HSP) hastalık şiddeti ve gidişatının belirlenmesindeki yeterliliğinin değerlendirilmesidir.

Materyal ve Metot: HSP hastası çocukların elektronik verileri tarandı. Hastalığın ciddiyeti adapte edilmiş bir klinik skorlama sistemi ile belirlendi. Tanı anındaki trombosit sayıs1, ortalama trombosit hacmi (MPV), plateletkrit (PCT) ve trombosit dağılım genişliği (PDW) belirteçleri kaydedildi.

Bulgular: Toplam 76 HSP hastası (ortalama yaş: 7,4 $\pm 2,5$ yıl, \%56,5 erkek) değerlendirildi, $59(\% 77,6)$ olguda HSP hafif ve $17(\% 22,4)$ olguda ciddiydi. Ciddi HSP olgularında MPV belirgin olarak düşüktü $(7,6 \pm 1,0$ vs. $8,44 \pm 1,1$, $p<0,01)$, ancak PCT ve PDW belirteçlerinde anlamlı bir fark yoktu. Hastaların 14'ünde relaps izlendi $(\% 18,4,5$ hafif HSP ve 9 ciddi HSP olgusu). Ciddi HSP olgularında relapsa yatkınlık daha fazlaydı $(p<0,01)$ ve relaps olan hastalarda PDW daha düşüktü $(13,2 \pm 3,1$ vs. $14,8 \pm 2,4$ $\mathrm{p}<0,05$ ).

Sonuç: HSP olgularında tanı anında saptanan MPV düzeyleri hafif ve ciddi hastalığın ayrımında faydalıdır. Ayrıca, düşük PDW düzeyleri relapse yatkınlığı olan HSP hastalarının ön görülmesinde yararlı olabilir.

Anahtar Kelimeler: Çocuk, Henoch-Schönlein purpura, ortalama trombosit hacmi, plateletkrit, trombosit dağ $11 \mathrm{~m}$ genişliği

\section{ABSTRACT}

Objecive: Our aim is to measure the discriminative competency of the qualitative platelet indices obtained at the time of diagnosis on the severity and outcome of HenochSchönlein purpura (HSP).

Materials and Methods: Electronic data of consecutive HSP children were extracted. The severity of the disease was estimated by an adopted clinical scoring system. Platelet count (PLT), mean platelet volume (MPV), plateletcrit (PCT), and platelet distribution width (PDW) indices at the time of diagnosis were recorded.

Results: Overall, 76 HSP patients (mean age: 7.4 \pm 2.5 years, $56.5 \%$ male) were evaluated. HSP was classified as mild in 59 (77.6\%) cases and severe in 17 (22.4\%). MPV was significantly lower in severe HSP patients $(7.6 \pm 1$ vs. $8.44 \pm 1.1, p<0.01)$, however, there was no significant difference for PCT and PDW parameters. Relapse occurred in 14 patients $(18.4 \%, 5$ mild HSP and 9 severe HSP patients) during follow up. Severe HSP cases were more prone to relapse $(p<0.01)$ and relapsing HSP patients had lower PDW (13.2 \pm 3.1 vs. $14.8 \pm 2.4 \mathrm{p}<0.05)$.

Conclusions: MPV level obtained at the time of first presentation of the HSP disease has a discriminative value for mild and severe HSP. Also, lower PDW might be predictive to suspect the HSP patients susceptive to relapse. Keywords: Children, Henoch-Schönlein purpura, mean platelet volume, plateletcrit, platelet distribution width

\section{Sorumlu Yazar / Corresponding Author:}

Nevzat Aykut Bayrak

Yayın Bilgisi / Article Info:

Zeynep Kâmil Kadın ve Cocuk Hastalıkları Eğitim ve Araștırma Kabul Tarihi/ Accepted: 01/12/2019

Hastanesi, Çocuk Gastroenteroloji Kliniği. Opr. Dr. Burhanettin Online Yayın Tarihi/ Published: 30/06/2020

Üstünel Cad. No:10, Üsküdar, İstanbul, Türkiye.

Tel: 02163910680 - Dahili: 1919

Fax: 02163910690

GSM: 05326231293

E-mail: aykutbayrak@hotmail.com

Atıf / Cited: Bayrak NA, Nuhoglu C. Predicting the Severity of Henoch-Schönlein Purpura: The Role of the Functional Platelet Indices. Online Türk Sağlık Bilimleri Dergisi 2020;5(2):330-338. doi: 10.26453/otjhs.620982 


\section{INTRODUCTION}

Henoch-Schönlein purpura (HSP) is an acute systemic small-vessel vasculitis involving especially skin, joints, gastrointestinal (GI) tract and kidneys. Children are primarily affected by an incidence of 20.4 cases per 100.000 annually. ${ }^{1}$ The exact pathogenesis is unknown. The principal clinical feature is non-thrombocytopenic palpable purpuric rash especially in buttocks and lower limbs. Arthritis/ arthralgia of any joint, abdominal pain, GI bleeding, hematuria and proteinuria are other common features. Despite its self-limited nature, severe abdominal pain; massive GI bleeding and intussusception are the feared acute complications. The major prognostic factor determining the long-term prognosis is the severity of renal involvement. ${ }^{2}$

Determining predictive factors for complications, relapses, and end-stage renal disease is still a challenge. In a previous report, thrombocytosis was common in childhood HSP and an association with renal and GI symptoms was described. ${ }^{3}$ Therefore, as well as the platelet quantity, quality is also important for bleeding diathesis. Qualitative platelet indices such as mean platelet volume (MPV), plateletcrit (PCT) and platelet distribution width (PDW) are routinely examined by almost all automated hematology analyzers. But these parameters are still overlooked by the majority of the clinicians. Activated platelets are larger, more functional and also more adhesive. ${ }^{4}$ Thrombocytopenic patients with marrow disease usually have small-sized platelets and are susceptible to bleed. ${ }^{5}$ A recent study suggests that low MPV may be a predictor for GI bleeding in HSP. ${ }^{6}$ Our aim is to investigate the relationship between the severity of the clinical presentation and outcome of HSP and qualitative platelet parameters obtained by a simple complete blood count (CBC) at the time of diagnosis.

\section{MATERIALS AND METHODS}

The present study is performed by evaluating the medical records of all children diagnosed as HSP in the Pediatric Department of Haydarpasa Numune Training and Research Hospital (Istanbul, Turkey) between November 2006 and June 2010. Our study was approved by the Ethics Committee of Haydarpasa Numune Training and Research Hospital (Date: 29/09/2010, decision no: 0164). The diagnosis of HSP was based on the following consensus criteria published by European League Against Rheumatism (EULAR) and Paediatric Rheumatology European Society (PRES), known as EULAR/PRES criteria ${ }^{7}$ : palpable purpura (mandatory criterion) in the presence of at least one of the four following criteria: [1] diffuse abdominal pain; [2] any biopsy showing predominant IgA deposition; [3] arthritis or arthralgia; [4] renal involvement (any hematuria and/or proteinuria).

Demographic, clinical and laboratory data were extracted from medical files and computerized hospital database. Regular medical follow-up of at least six months was an inclusion criterion. Files with insufficient data, patients do not fulfill the EULAR/PRES criteria and patients with other known chronic disease (renal, GI and neurological) were excluded. White blood cell (WBC), hematocrit (Hct), platelet count (PLT), MPV, PCT and PDW parameters at the time of diagnosis were recorded.

The severity of the disease was estimated by an adopted clinical scoring system previously used in some other studies. ${ }^{8-10}$ Joint, abdominal and renal symptoms were scored from 0 to 3 as reported in Table 1. The highest score reached during 6 months of follow-up was considered as the total score. Severity of the disease was determined as mild or severe if the total score was $\leq 4$ and $>4$ respectively. Relapse was defined as the resumption of the disease after a period of a complete symptom-free interval of at least 1 month.

The study protocol was approved by the local institutional ethical board. Statistical analysis was performed by Graphpad Instat ver. 3.05 (Graphpad Software Inc. San Diego, CA, USA). All data were analyzed in terms of mean \pm standard deviation (SD). For continuous variables, the Mann-Whitney $\mathrm{U}$ test or unpaired t-test with Welch correction was used to analyze the variance among groups where appropriate. Fisher's exact test was used for comparison of categorical variables. $P \leq 0.05$ was considered significant.

\section{RESULTS}

We evaluated a total of 76 HSP patients (43 males, 33 females). The mean age at onset was $7.4 \pm 2.5$ years. All the patients had palpable purpura. Fortythree patients $(57.3 \%)$ were also confirmed by a skin biopsy including 2 patients with an atypical purpuric distribution. Arthralgia or arthritis was found in 61 patients (80.2\%). Fifty-three patients $(69.7 \%)$ had abdominal pain that is complicated by occult blood in the stool of $25(32.8 \%)$; melena in $4(5.2 \%)$ and hematemesis in $1(1.3 \%)$, intussusception was none. Twenty-nine patients (38.1\%) had hematuria. Eighteen patients $(23.6 \%)$ had proteinuria of varying se- 
verity. The detected proteinuria was in the range of $30-150 \mathrm{mg} / \mathrm{dl}$ in 6 cases $(7.9 \%)$ and proteinuria recovered in 5 patients spontaneously. Other 6 patients had proteinuria over $150 \mathrm{mg} / \mathrm{dl}$ and spontaneous recovery was only in 3 cases. Renal biopsy in four patients $(5.2 \%)$ with persisting proteinuria resulted in nephrotic syndrome.

HSP was classified as mild in 59 patients $(77.6 \%)$ and severe in $17(22.4 \%)$ according to the clinical scoring system shown in Table 1 . Distribution of patient scores are summarized in Table 2. Mean joint, abdominal and renal scores were $1.4 \pm 0.85$, $1.01 \pm 0.88$ and $0.74 \pm 0.94$, respectively; the mean total score was $3.13 \pm 1.57$. For the severe HSP patients, mean joint, abdominal, and renal scores were $1.64 \pm 0.86,1.76 \pm 0.83,2.05 \pm 0.82$ respectively; the mean total score was $5.47 \pm 0.87$.

CBC parameters obtained in the onset of the disease for mild and severe HSP patients were indicated in Table 3. MPV was significantly lower in severe HSP patients $(7.6 \pm 1$ vs. $8.44 \pm 1.1, P<0.01)$. Thrombocytosis was a more common finding in severe HSP patients ( $P<0.05$, OR: 4.19 , CI 95\%: 1.3-12.9).

There were 46 cases $(60.5 \%)$ with blood loss which was isolated to the urinary tract in $16(34.8 \%)$, GI tract in $17(37 \%)$ while $13(28.2 \%)$ had blood in both urine and stool. CBC parameters of isolated hematuria and isolated GI blood loss didn't differ significantly with non-bleeding patients. A significant difference was found in Hct between nonbleeding patients and patients with blood loss both from urinary and GI tract ( $37.17 \pm 4.9$ vs. $34.66 \pm 2.3$, $P<0.05)$.

Relapse occurred in 14 patients (18.4\%, 5 mild HSP patients and 9 severe HSP patients) during follow up. Severe HSP patients were more prone to relapse $(P<0.01)$. Eight of these patients had varying degrees of proteinuria and 3 of them had massive proteinuria and biopsy-confirmed nephrotic syndrome. The rest of the relapses were isolated to skin and joints. CBC parameters obtained in the onset of the disease for relapsing and non-relapsing HSP patients were indicated in Table 4 . There was a slight significance that relapsing HSP patients had lower PDW (13.2 \pm 3.1 vs. $14.8 \pm 2.4 P<0.05)$. The normal value range of the center's laboratory is $12-26 \%$ for PDW. None of the patients had values higher than the upper limit. Nine patients of non-relapsing HSP group and 6 patients of relapsing HSP group had lower PDW levels than the lower limit. Lower PDW was a more common finding in relapsing HSP patients $(P<0.05$, OR: 4.41, CI 95\%: 1.2-15.7).

\section{DISCUSSION AND CONCLUSION}

MPV, PCT, and PDW are simple parameters that reflect the volume of platelets and their levels are easily obtained by a simple CBC count on automated analyzers. By examining these qualitative parameters, we revealed that; MPV levels were decreased in HSP patients with severe joint, GI and renal symptoms. Moreover, this was not limited only to patients with GI bleeding as reported previously in another study. ${ }^{6}$ Besides, a significant difference in PCT levels was absent but we found that relapsing HSP patients had lower PDW levels. HSP is defined as a non-thrombocytopenic vasculitis in which routine coagulation screening test results are also generally considered to be normal. Because of the endothelial damage and inflammation, platelets and coagulation cascade are expected to be activated. Larger platelets are more functional in maintaining the homeostasis. ${ }^{4,5}$ Small platelets facilitate bleeding as their functional capacity is smaller.

Decreased MPV is also reported previously in the active stage of inflammatory diseases such as ankylosing spondylitis, rheumatoid arthritis, Crohn's disease, and ulcerative colitis, where normal levels were acquired after the suppression of the inflammation. ${ }^{11-14}$ Common characteristic of those is systemic inflammation. Some authors speculated that the reduced MPV could be due to the consumption or sequestration of the activated platelets during inflammation. ${ }^{15}$ Other speculated mechanism for decreased MPV is the presence of a defect in the regulation of thrombopoiesis during an insult. ${ }^{13}$ We support these speculations and also speculate that while the platelets are activated during an acute phase reaction, excessive degranulation as a response to inflammation might also cause a significant volume loss. Besides, the balance between the need for large activated platelets and high consumption rates might be the cause of thrombocytosis.

Alterations in the production of interleukins and growth factors may also have a role in the pathogenesis of HSP. It is reported that tumor necrosis factor, interleukin 1, and interleukin 6 may mediate the inflammatory process present in HSP. ${ }^{16,17}$ Lately, it is shown that anti-TNF- $\alpha$ therapy causes a significant increase in MPV levels of rheumatoid arthritis patients $^{18}$, and also, recombinant human IL-6 administration causes a decrease in MPV levels of cancer patients. ${ }^{19}$ Thrombocytosis and low MPV in the acute stage of HSP may be linked to these cytokines. Vagdatli et al. suggested the combined use of MPV and PDW, regarding PDW as a more specific indica- 
tor of platelet activation than MPV since no elevation was observed in PDW levels during single platelet swelling. ${ }^{20}$ It means that only an advanced loss in whole platelet size might cause a decrease in PDW. Even it is debatable because of the slight significance, our result suggesting PDW level at the time of diagnosis as a predictive factor for relapse might be important in clarifying the pathogenesis of HSP and relapses. This slight significance might also be influenced by the short follow up period defined in the study design. This evidence must be further analyzed in prospective studies. The link between the platelet size and HSP relapse might be caused by a specific immunomodulatory cytokine which becomes functional at the beginning of the disease, suppressed or cleared during the convalescence or well-being period and if not completely cleared, reactivated by the loss of suppression and cause a relapse.

Our study has some limitations. Comparative statistics with a healthy control group for these platelet parameters would be a good addition to our study design. However, we only focused on these parameters of HSP patients because of ethical and funding issues.

In conclusion, the present study suggests that MPV level obtained in the diagnosis time of the HSP disease has a discriminative value for mild and severe HSP. Also, lower PDW might be predictive to suspect the HSP patients susceptive to relapse. PCT doesn't seem to have any influence on the course of HSP disease. The use of these parameters is inexpensive and requires no extra technical effort. Further clinical studies must be designed for evaluating the factors and pathogenesis affecting the platelet size in HSP and other inflammatory diseases.

Ethics Committee Approval: Our study was approved by the Ethics Committee of Haydarpasa Numune Training and Research Hospital (Date: 29/09/2010, decision no: 0164).

Conflict of Interest: No conflict of interest was declared by the authors.

Author Contributions: Concept - NAB; Supervision - CN; Materials - NAB; Data Collection and/or Processing - NAB; Analysis and/ or Interpretation NAB, CN; Writing - NAB, CN.

Peer-review: Externally peer-reviewed.

\section{REFERENCES}

1. Gardner-Medwin JM, Dolezalova P, Cummins C, Southwood TR. Incidence of Henoch-Schonlein purpura, Kawasaki disease, and rare vasculitides in children of different ethnic origins. Lancet. 2002;360:1197-1202.

2. Çakıcı EK, Gür G, Yazılıtaş F, ve ark. A retrospective analysis of children with HenochSchonlein purpura and re-evaluation of renal pathologies using Oxford classification. Clin Exp Nephrol. 2019;23(7):939-947. doi: 10.1007/ s10157-019-01726-5

3. Elmas AT, Tabel Y. Platelet Counts in Children with Henoch-Schonlein Purpura Relationship to Renal Involvement. J Clin Lab Anal. 2016;30 (1):71-74.

4. Thompson CB, Eaton KA, Princiotta SM, Rushin CA, Valeri CR. Size dependent platelet subpopulations: relationship of platelet volume to ultrastructure, enzymatic activity, and function. Br J Haematol. 1982;50(3):509-519.

5. Bowles KM, Cooke LJ, Richards EM, Baglin TP. Platelet size has diagnostic predictive value in patients with thrombocytopenia. Clin Lab Haematol. 2005;27(6):370-373.

6. Makay B, Türkyilmaz Z, Duman M, Unsal E. Mean platelet volume in Henoch-Schönlein purpura: relationship to gastrointestinal bleeding. Clin Rheumatol. 2009;28(10):1225-1228.

7. Ozen S, Ruperto N, Dillon MJ, ve ark. EULAR/ PReS endorsed consensus criteria for the classification of childhood vasculitides. Ann Rheum Dis. 2006;65(7):936-941.

8. De Mattia D, Penza R, Giordano P, ve ark. von Willebrand factor and factor XIII in children with Henoch-Schonlein purpura. Pediatr Nephrol. 1995;9(5):603-605.

9. Muslu A, Islek I, Gok F, ve ark. Endothelin levels in Henoch-Schonlein purpura. Pediatr Nephrol. 2002;17(11):920-925.

10. Fessatou S, Nicolaidou P, Gourgiotis D, ve ark. Endothelin 1 levels in relation to clinical presentation and outcome of Henoch Schonlein purpura. BMC Pediatr. 2008;8:33.

11. Kisacik B, Tufan A, Kalyoncu U, ve ark. Mean platelet volume (MPV) as an inflammatory marker in ankylosing spondylitis and rheumatoid arthritis. Joint Bone Spine. 2008;75(3):291-294.

12. Kapsoritakis AN, Koukourakis MI, Sfiridaki A, ve ark. Mean platelet volume: a useful marker of inflammatory bowel disease activity. Am J Gastroenterol. 2001;96(3):776-781.

13. Yüksel O, Helvaci K, Başar O, ve ark. An overlooked indicator of disease activity in ulcerative colitis: mean platelet volume. Platelets. 2009;20 
(4):277-281.

14. Culic S, Jakl R, Metlicic V, ve ark. Platelet function analysis in children with Schönlein-Henoch syndrome. Arch Med Res. 2001;32(4):268-72.

15. Collins CE, Rampton DS, Rogers J, Williams NS. Platelet aggregation and neutrophil sequestration in the mesenteric circulation in inflammatory bowel disease. Eur J Gastroenterol Hepatol. 1997;9:1213-1217.

16. Rostoker G, Rymer JC, Bagnard G, Petit-Phar M, Griuncelli M, Pilatte Y. Imbalances in serum proinflammatory cytokines and their soluble receptors: a putative role in the progression of idiopathic IgA nephropathy (IgAN) and HenochSchonlein purpura nephritis, and a potential target of immunoglobulin therapy? Clin Exp Immunol. 1998;114(3):468-476.

17. Wu TH, Wu SC, Huang TP, Yu CL, Tsai CY: Increased excretion of tumor necrosis factor alpha and interleukin 1 beta in urine from patients with IgA nephropathy and Henoch-Schonlein purpura. Nephron. 1996;74(1):79-88.

18. Gasparyan AY, Sandoo A, StavropoulosKalinoglou A, Kitas GD. Mean platelet volume in patients with rheumatoid arthritis: the effect of anti-TNF- $\alpha$ therapy. Rheumatol Int. 2010;30 (8):1125-1129.

19. van Gameren MM, Willemse PH, Mulder NH, ve ark. Effects of recombinant human interleukin-6 in cancer patients: a phase I-II study. Blood. 1994;84(5):1434-1441.

20. Vagdatli E, Gounari E, Lazaridou E, Katsibourlia E, Tsikopoulou F, Labrianou I. Platelet distribution width: a simple, practical and specific marker of activation of coagulation. Hippokratia. 2010;14(1):28-32. 
Table 1. The clinical scoring system in patients with HSP. ${ }^{8-10}$

\begin{tabular}{|c|c|}
\hline \multirow[t]{4}{*}{ Joint score } & $0=$ No symptom \\
\hline & $1=$ arthralgia and/or slight swelling or arthritis with a normal walk \\
\hline & $2=$ arthralgia and/or moderate swelling or arthritis with a limp walk \\
\hline & $3=$ arthralgia and/or severe swelling or arthritis with refuse to walk \\
\hline \multirow{4}{*}{$\begin{array}{l}\text { Abdominal } \\
\text { score }\end{array}$} & $0=$ No symptom \\
\hline & 1 = mild abdominal pain (medically elicited) and/or occult blood in stool $(+)$ \\
\hline & $\begin{array}{l}2=\text { moderate abdominal pain (transient complaints brought to medical attention) and/or occult } \\
\text { blood in stool }(++/+++)\end{array}$ \\
\hline & $3=$ severe abdominal pain and/or melena and/or hematemesis and/or intussusception \\
\hline \multirow[t]{4}{*}{ Renal score } & $0=$ No proteinuria and/or $\leq 5 \mathrm{RBC} / \mathrm{HPF}$ \\
\hline & $1=$ proteinuria $<30 \mathrm{mg} / \mathrm{dl}$ and/or microalbuminuria and/or $6-50 \mathrm{RBC} / \mathrm{HPF}$ \\
\hline & $2=$ proteinuria $30-150 \mathrm{mg} / \mathrm{dl}$ and $/$ or $>50 \mathrm{RBC} / \mathrm{HPF}$ \\
\hline & $3=$ proteinuria $>150 \mathrm{mg} / \mathrm{dl}$ and/or macroscopic hematuria \\
\hline
\end{tabular}


Table 2. The distribution of the HSP severity scores of the study group $(n=76)$.

\begin{tabular}{|l|c|c|c|}
\hline Score & $\begin{array}{c}\text { Joint Score } \\
\text { (n) }\end{array}$ & $\begin{array}{c}\text { Abdominal Score } \\
\text { (n) }\end{array}$ & $\begin{array}{c}\text { Renal Score } \\
\text { (n) }\end{array}$ \\
\hline $\mathbf{0}$ & $13(17.1 \%)$ & $23(30.2 \%)$ & $42(55.3 \%)$ \\
$\mathbf{1}$ & $24(31.6 \%)$ & $35(46.1 \%)$ & $20(26.3 \%)$ \\
$\mathbf{2}$ & $34(44.7 \%)$ & $12(15.8 \%)$ & $8(10.5 \%)$ \\
$\mathbf{3}$ & $5(6.6 \%)$ & $6(7.9 \%)$ & $6(7.9 \%)$ \\
\hline
\end{tabular}


Table 3. Comparison of complete blood count parameters between mild and severe HSP patients.

\begin{tabular}{|l|c|c|c|}
\hline Parameter & $\begin{array}{c}\text { Mild HSP patients } \\
(\mathbf{n}=\mathbf{5 9}) \\
(\mathbf{m e a n} \pm \mathbf{S D})\end{array}$ & $\begin{array}{c}\text { Severe HSP patients } \\
(\mathbf{n}=\mathbf{1 7}) \\
(\mathbf{m e a n} \pm \mathbf{S D})\end{array}$ & P value \\
\hline Age & $7.4 \pm 2.7$ & $7.46 \pm 1.5$ & 0.95 \\
\hline WBC (x10 $\mathbf{3} / \boldsymbol{\mu L )}$ & $11.2 \pm 4.4$ & $11.6 \pm 4.4$ & 0.72 \\
\hline Het (\%) & $36.5 \pm 4.1$ & $35 \pm 3.5$ & 0.14 \\
\hline PLT (x10 $/ \boldsymbol{\mu L})$ & $344.6 \pm 96.1$ & $394.3 \pm 96.2$ & 0.07 \\
\hline MPV (fL) & $8.44 \pm 1.1$ & $7.6 \pm 1$ & $\mathbf{0 . 0 0 7}$ \\
\hline PCT (\%) & $0.297 \pm 0.09$ & $0.380 \pm 0.1$ & 0.7 \\
\hline PDW (\%) & $14.7 \pm 2.4$ & $13.8 \pm 3$ & 0.25 \\
\hline
\end{tabular}


Table 4. Comparison of complete blood count parameters between relapsing and non-relapsing HSP patients.

\begin{tabular}{|l|c|c|c|}
\hline Parameter & $\begin{array}{c}\text { Non-relapsing HSP } \\
\text { patients } \\
(\mathbf{n}=\mathbf{6 2}) \\
(\mathbf{m e a n} \pm \text { SD) }\end{array}$ & $\begin{array}{c}\text { Relapsing HSP } \\
\text { patients } \\
(\mathbf{n}=\mathbf{1 4}) \\
(\mathbf{m e a n} \pm \text { SD) }\end{array}$ & P value \\
\hline Age & $7.5 \pm 2.6$ & $7.03 \pm 2$ & 0.49 \\
\hline WBC (x10 $/ \boldsymbol{\mu L})$ & $11.1 \pm 4.5$ & $11.9 \pm 4.2$ & 0.33 \\
\hline Hct (\%) & $36.2 \pm 4.2$ & $35.9 \pm 2.9$ & 0.43 \\
\hline PLT (x10 $/ \boldsymbol{\mu L})$ & $353.3 \pm 99.6$ & $366.5 \pm 91.5$ & 0.49 \\
\hline MPV (fL) & $8.33 \pm 1.2$ & $7.9 \pm 1.07$ & 0.32 \\
\hline PCT (\%) & $0.297 \pm 0.09$ & $0.312 \pm 0.11$ & 0.54 \\
\hline PDW (\%) & $14.8 \pm 2.4$ & $13.2 \pm 3.1$ & $\mathbf{0 . 0 4}$ \\
\hline
\end{tabular}

